\title{
Eclogite Xenoliths from Kimberley, South Africa - a Case Study of Extensive Mantle Metasomatism
}

\author{
D.E. Jacob ${ }^{1}$, K.S. Viljoen ${ }^{2}$ and N. Grassineau ${ }^{3}$ \\ 1 Institut für Geowissenschaften, Johannes Gutenberg Universität Mainz, Becherweg 21, D-55099 Mainz, FRG \\ 2 Mintek, Mineralogy Division, 200 Malibongwe Drive, Randburg, 2125, South Africa \\ 3 Department of Geology, Royal Holloway University of London, Egham, Surrey TW20 0EX, UK
}

\begin{abstract}
Introduction
Mantle xenoliths from the Kimberley kimberlite pipes in South Africa provide evidence for extensive metasomatic alteration of the Kaapvaal craton lithosphere. Peridotitic rocks from this type locality of mantle metasomatism (Dawson 1984) are characterized by considerable modal amounts of hydrous potassium silicates, such as phlogopite, K-amphiboles and (more rarely) K-Ba-rich titanates. Apart from a strong enrichment of the bulk rock in potassium and water compared to primitive mantle, their trace element budget is highly enriched in high field strength and large ion lithophile elements (HFSE, LILE). Two types of metasomatic overprint can be distinguished by compositional and textural characteristics: The first is characterized by increasing degrees of introduction of K-rich phases in garnet-peridotites, forming garnetphlogopite, phlogopite and phlogopite-K-richterite peridotites (e.g. Erlank et al., 1987) while the second type produced MARIDs (phlogopite + clinopyroxene + ilmenite/rutile \pm K-richterite rocks). Both types of metasomatism have been linked geochronologically with Group I and II kimberlite magmatism. In addition to abundant peridotite xenoliths, the kimberlites in this locality transported a small amount of eclogite xenoliths to the surface. Eclogites are an integral part of the subcratonic lithosphere and are estimated to amount to ca. $1 \%$ under the Kaapvaal craton. The eclogite samples from the Boshof Road Dump are strongly metasomatized, similar to the peridotites and provide examples for the effect of mantle metasomatism on the eclogite component in the cratonic lithosphere.
\end{abstract}

\section{Samples and Petrography}

The collection consists of twenty-one eclogite samples that were collected over several years from the Boshof Road Dump and the Yacht Club Dump in Kimberley, South Africa. Mantle material from these Diamond Mine dumps comes mainly from the Bultfontein kimberlite. All samples consist of garnet, omphacite and phlogopite, sometimes sulphides and rutiles are observed. One sample additionally contains kyanite, one has olivine and one is orthopyroxene-bearing. Garnet and omphacite range in modal amounts between $60: 40$ and 30:70, very garnet-rich lithologies as in other localities are not observed. Garnet and clinopyroxene are both very coarse-grained (Fig. 1) and some of the samples show a parallel structure. Larger clinopyroxene grains contain abundant garnet exsolution lamellae. Phlogopite occurs as large idiomorphic grains apparently of primary origin (i.e. not as overgrowth). No replacement textures were recognized. Modal amounts of phlogopite range between 10 and $20 \%$ approximately.

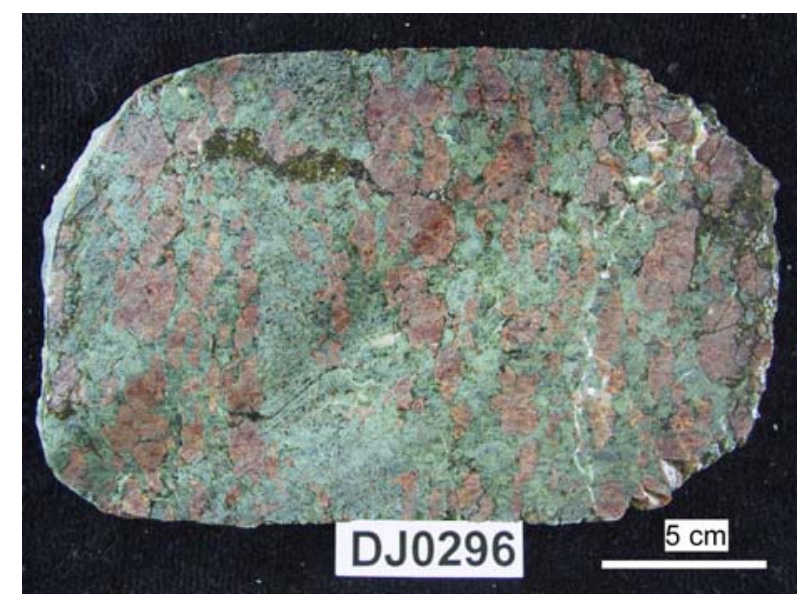

Fig.1: A sectioned eclogite xenolith from the Yacht Club Dump, Kimberley, South Africa.

\section{Analytical Methods}

Major element compositions of garnet, clinopyroxene, orthopyroxene, olivine and phlogopite were analysed with a JEOL JXA 8900 RL electron microprobe at the Department of Geosciences, Johannes GutenbergUniversity Mainz, Germany, using wavelength dispersive analysis and a range of natural and synthetic standards. The data were corrected using the CITZAF procedure (Armstrong, 1995). Detection limits were generally between 0.01 and 0.07 wt. \% except for fluorine in phlogopite (0.17 wt. \%).

Trace elements were analysed in situ by Laser Ablation - Inductively Coupled Plasma Mass Spectrometry (LAICP-MS) at the Department of Geosciences, Johannes Gutenberg-University, Mainz, using an Agilent 7500ce quadrupole ICP-MS coupled to a New Wave Research UP-213 laser ablation system (Jacob 2006). 
Measurements were carried out with laser energy densities of $\sim 6.5 \mathrm{~J} / \mathrm{cm}^{2}$ and Ar-He mixtures were used as carrier gas. All measurements were performed on polished thin sections using a spot size of $100 \mu \mathrm{m}$. Electron microprobe measurements of $\mathrm{Ca}$ and Si were used as internal standards to calculate concentrations from LA-ICP-MS data with SRM NIST 612 glass as external standards (Jochum and Nehring, 2006). Data reduction was carried out with the commercially available software GLITTER version 4 (Macquarie University).

\section{Major Elements and oxygen isotopes}

Garnet compositions (Fig. 2) are homogeneous and range from $\mathrm{Grs}_{10}$ to $\mathrm{Grs}_{42}$ and overlap with the compositional range observed for Roberts Victor eclogite garnets. Grossular-rich compositions (grospydites) are not observed. Garnet exsolution lamellae in omphacites (Fig. 1) are slightly more pyropic than discrete garnets in the same sample. Omphacites have variable jadeite contents and are $\mathrm{Jd}_{6}$ to $\mathrm{Jd}_{23}$. Applying the Mg-Fe exchange thermometer (Ellis and Green 1979) to garnet and cpx yields an average equilibration temperature of $1156 \pm 50^{\circ} \mathrm{C}$ for the sample set at an assumed pressure of $5 \mathrm{GPa}$.

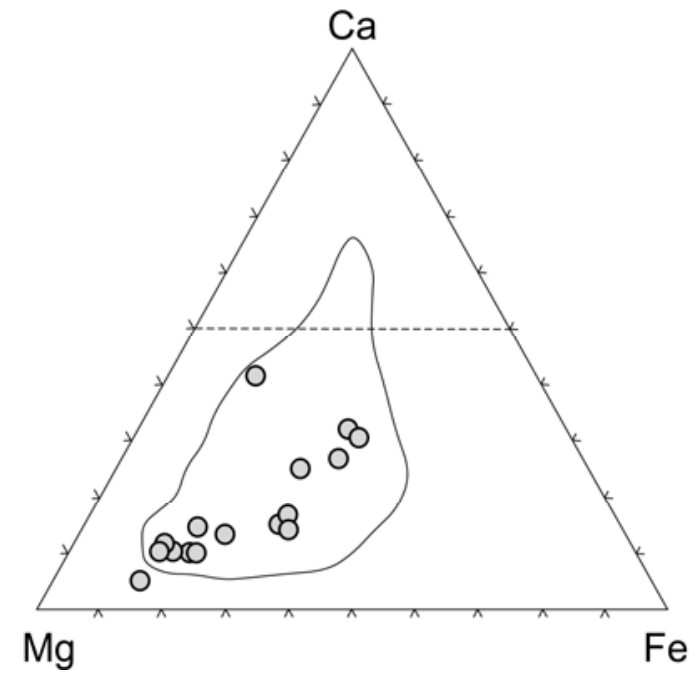

Fig.2: Trilateral garnet compositions for the Kimberley eclogite xenoliths (grey circles) compared with the field of garnet compositions for Roberts Victor eclogites (from Jacob 2004).

Phlogopites are highly magnesian with Mg-numbers ranging between 79.4 and 94.1 and have $\mathrm{TiO}_{2}$ contents between 0.35 and 2.07 wt $\%$. FeO contents in phlogopite range between 2.8 and 9.47 wt\%. Oxygen isotopic values for clinopyroxene and garnet are in the range of unchanged mantle values $\left(\delta^{18} \mathrm{O}=4.51-5.35\right.$ \%) and, thus, show no evidence of involvement of a crustal component during metasomatic overprint. Recalculated bulk rock compositions with $10 \%$ modal amount of phlogopite yields compositions with a range of Mg-numbers between 63 and 86 which is towards the high end of the range for eclogite xenoliths worldwide. Using $12 \mathrm{wt} \% \mathrm{MgO}$ as a cut-off, only 3 samples have basaltic bulk compositions, while all others are picritic.

\section{Trace element compositions}

Trace element compositions are well equilibrated and have rather uniform patterns in garnet and clinopyroxene with highly enriched heavy Rare Earth Element (HREE) concentrations in garnets (up to 140 times chondritic) and, likewise, highly enriched Light Rare Earth Element (LREE) patterns in the clinopyroxenes (up to 100 times chondritic). The observed enrichment of HREE in the garnets exceeds that of garnets in metasomatized garnet peridotites reported by Grégoire et al. (2003) (Fig. 3). Phlogopites are not as homogeneous in composition and some samples show both grain-to-grain and within grain heterogeneity in trace element concentrations. Within the sample suite, Ni-concentrations range between 41 and 7256 ppm, 270-10,124 ppm Cr and 10.5 - 2360 ppm V. Zr-contents of the phlogopites are 1.9354.3ppm, Sr ranges between 26.3 and 845 ppm and Bacontents are 38-60,261 ppm.

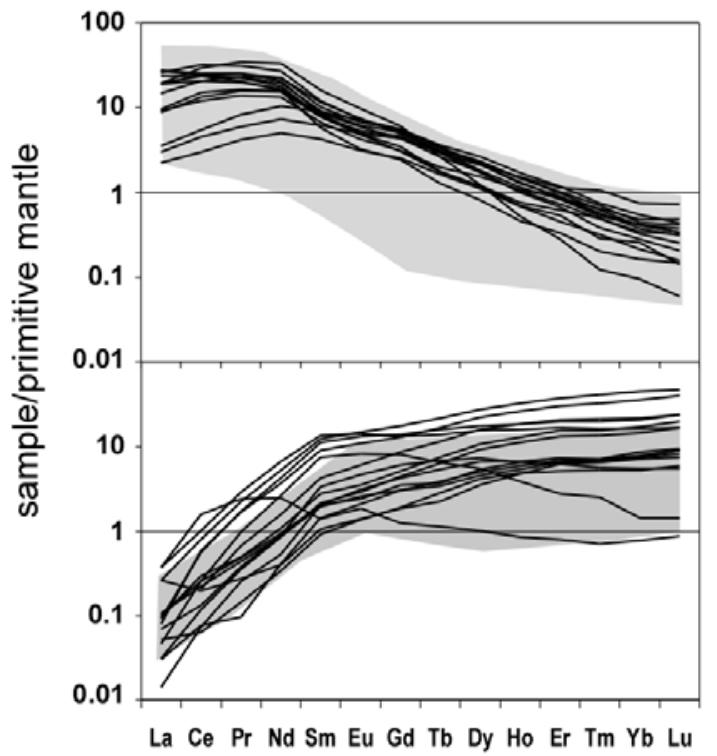

Fig.3: REE concentrations in garnets and clinopyroxene from Kimberley eclogite xenoliths compared to REE patterns from metasomatized garnet peridotites from the Kaapvaal craton (grey field, Grégoire et al., 2003)

Trace element compositions of the reconstructed bulk rocks are enriched compared to primitive mantle and show prominent positive niobium and tantalum anomalies as well as negative titanium anomalies (Fig. 4) for some of the samples. These enrichments in $\mathrm{Nb}$, $\mathrm{Ta}$ and $\mathrm{Sr}$ are signatures of phlogopite addition which contains high concentrations of these trace elements in this sample suite $(\mathrm{Nb}=6.2-489 \mathrm{ppm}$, $\mathrm{Ta}=0.89-19.4$ ppm). Eclogite xenoliths from kimberlites from the Canadian Slave craton are also known for HFSE enrichment (Heaman et al., 2002, Jacob et al., 2003). Fig. 4 compares one example of an ilmenite-bearing eclogite xenolith from the Grizzly kimberlite pipe 
(Ekati kimberlite area, Central Slave craton, Canada) which shows a similar enrichment in $\mathrm{Nb}$ and $\mathrm{Ta}$. Since in this sample, ilmenite is the major carrier of the HFSE, as opposed to phlogopite in the Kimberley suite, Ti is strongly enriched as well, while Sr shows a negative anomaly.

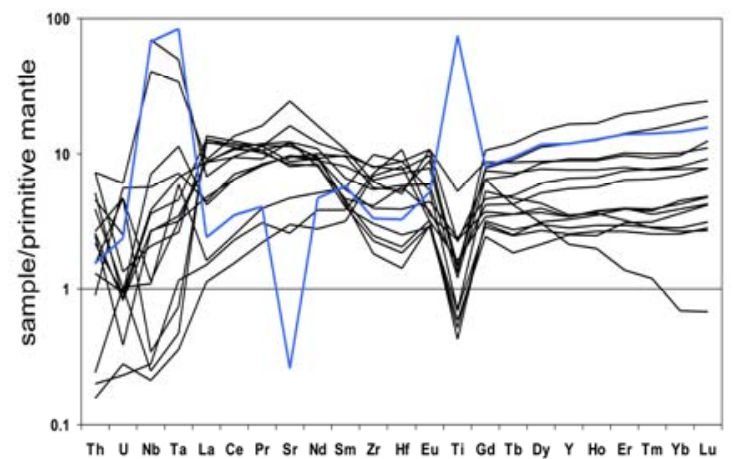

\section{References}

Armstrong, A., 1995. CITZAF - A package of correction programs for the quantitative electron microbeam X-rayanalysis of thick polished materials, thin-films, and particles. Microbeam Analysis 4, 177-200.

Dawson, J.B., 1984. Contrasting types of upper mantle metasomatism? In: Kornprobst, J. (Ed.), Kimberlites II: The mantle and crust-mantle relationship. Proceedings of the $3^{\text {rd }}$ International Kimberlite Conference, Elsevier Science, Oxford, 289-295.

Ellis, D.J. and Green, D.H., 1979. An experimental study of the effect of Ca upon garnet-clinopyroxene Fe-Mg exchange equilibria. Contributions to Mineralogy and Petrology, 71:

13-22.

Erlank, A.J., Waters, F.G., Hawkesworth, C.J., Haggerty, S.E., Rickard, R.S., Menzies, M., 1987. Evidence for mantle metasomatism in peridotite nodules from the Kimberley Pipes, South Africa. In: Menzies, M., Hawkesworth, C.J. (Eds.), Mantle Metasomatism. Academic Press, London, 221312.

Grégoire, M., Bell, D.R., Le Roex, A. P., 2003. Garnet lherzolites from the Kaapvaal craton (South Africa): Trace element evidence for a metasomatic history. Journal of Petrology 44 (4), 629-657.

Heaman, L.A., Creaser, R.A. and Cookenboo, H.O., 2002. Extreme enrichment of high field strength elements in Jericho eclogite xenoliths: a cryptic record of Paleoproterozoic subduction, partial melting, and metasomatism beneath the Slave Cracton, Canada. Geology, 30: 507-510.

Jacob, D.E., 2004. Nature and origin of eclogites from the Earth's mantle. Lithos, 77 (1-4) (Proceedings of the $8^{\text {th }}$ International Kimberlite Conference), 295-316.

Jacob, D.E., 2006. High sensitivity analysis of trace element poor geological reference glasses by laser-ablation inductively coupled plasma mass spectrometry (LA-ICPMS). Geostandards and Geoanalytical Research, 30, No. 3, 221-235.

Jacob, D.E., Fung, A., Jagoutz, E., Pearson, D.G. (2003). Petrology and Geochemistry of eclogite xenoliths from the Ekati kimberlites area. Extended Abstracts 8th International Kimberlite Conference, Vancouver, Canada.

Jochum, K. P. and Nehring, F., 2006. GeoReM preferred values. http://georem.mpch-mainz.gwdg.de/.

Sun, S.-S. and McDonough, W.F., 1989. Chemical and isotopic systematics of oceanic basalts: implications for mantle composition and processes. In: A.D. Saunders and MJ. Norry (Eds), Magmatism in the ocean basins. Geoldgical Society Special Publication, 313-345.
Fig. 4: Spidergram for reconstructed bulk rocks of the Kimberley eclogites, normalized to primitive mantle values (Sun and McDonough, 1989). The blue line is an ilmenite-bearing eclogitic xenoliths from the Grizzly kimberlite pipe, Slave craton, Canada (Jacob et al., 2003) for comparison. 